\title{
Regimen Used to Treat Kaposi Sarcoma
}

National Cancer Institute

\section{Source}

National Cancer Institute. Regimen Used to Treat Kaposi Sarcoma. NCI Thesaurus. Code C159449.

Any regimen that can be used for the treatment of Kaposi sarcoma. 